\title{
MASALAH PENYEDIAAN LAHAN DALAM PENGEMBANGAN KOTA
}

\author{
Oleb: Mob. Musyiam
}

\section{ABSTRACT}

In fact, the problem of land in cities is rooted in the limitedness of stock of land. on the other hand, the need of land increase in accordance with the increasing of the inhabitant and activities in cities. the next problem is the land value. The land value increase rapindly that is followed by the extend of land speculation; the glow of social conflict as a result of the comdemnation and deliverance of land, and conflict of interest among the sectoral in landuse.

Because of the complexity of land problem in cities, the integrated strategy and comprebensive that able to accomodate many interest and interrelated aspects is needed.

\section{INTISARI}

Masalab di perkotaan sesunggubnya berakar dari keterbatasan penyediaan lahan. Dilain pibak permintaan akan laban semakin bertambah sejalan dengan pertambahan jumlab penduduk dan aktifitas perkotaan. Masalab yang muncul kemudian adalab harga laban yang meningkat dengan cepat diikuti dengan munculnya spekulan-spekulan laban, merebaknya konflik sosial sebagai akibat dari penggusuran dan pembebasan tanab serta konflik kepentingan masing-masing sektoral dalam penggunaan laban. Oleh karena masalab laban di perkotaan demikian komplek, maka diperlukan strategi yang terpadu cian menyelurub yang dapat mengakomodasikan berbagai kepentingan masyarakat dan aspek terkait yang diperlukan.

\section{PENDAHULUAN}

Pertambahan penduduk kota Indonesia mendorong meningkatnya kegiatan kehidupan sosial ekonomi di kota, yang sclanjutnya menyebabkan kenaikan kebutuhan akan lahan Kebutuhan lahan wilayah perkotaan terutama berhubungan dethgan perluasan ruang kota untuk digunakan bagi prasarana kota seperti perumahan, jaringan air minum, jaringan sanitasi, taman-taman dan lapangan olahraga. Penyediaan la- han yang sangat terbatas untuk mencukupi kebutuhan-kebutuhan tersebut cenderung mengakibatkan kenaikkan harga lahan, yang selanjut mendorong meluasnya spekulasi tanah sehingga menyebabkan pola penggunaan lahan yang kurang efisien di perkotaan. Selain itu perkembangan kota yang pesat akan cenderung menurunkan kualitas lingkungan kota, seperti menurunnya kapasitas dan kualitas air, terutama air tanah, apabila tidak dikendalikan scca. ra baik. 
Tulisan ini dimaksudkan untuk mengidentifikasi masalah-masalah penycdiaan lahan di perkotaan dalam kaitannya dengan pengembangan kota. Pembahasan dimulai dari pertama, mengenai perubahan fisik kota dan implikasi yang ditimbulkannya; kedua, masalah lahan di kota dan aspek-aspeknya dan diakhiri dengan pembahasan beberapa pemecahan masalah lahan di perkotaan.

\section{PERUBAHAN FISIK KOTA DAN IMPLIKASINYA}

Salah satu akibat dari pertumbuhan penduduk perkotaan adalah perubahan tatakeruangan kota yang tercermin dari perubahan fisik kota, perubahan lingkungan kota dan perubahan tataguna lahan kota.

Perubahan fisik kota dipengaruhi oleh kebutuhan ruang yang semakin meningkat, baik untuk tempat tinggal maupun untuk keperluan menopang fungsi-fungsi perkotaan yang semakin meningkat. Perubahan fisik kota secara garis besar dapat dikelompokkan dalam dua kategori, yakni perubahan ekstensif dan perubahan intensif (Dilahur, 1990).

Perubahan ekstensif yaitu perluasan areal perkotaan yang kadang- kadang melampaui batas administrasi kota yang bersangkutan. Perkembangan demikian lazim disebut dengan pemekaran kota (urban sprawl) yang dapat terjadi secara alamiah (tidak disengaja) maupun karena direncanakan oleh Pemerintah Daerah yang bersangkutan. Menurut Rachmadi B. Soemadhijo (1993) pemekaran fisik kota-kota di Indonesia pada dekade 1980-an lebih banyak bersifat melompat (leap frog development). Menurutnya, secara umum fenomena di atas discbabkan oleh bc. berapa hal. Pertama, terjadinya perkembangan kegiatan pembangunan perkotaan yang sangat cepat kurang dapat diakomodasi dalam rencana penataan ruang kota. Kedua, kurangnya kemampuan penyediaan sarana dan prasarana perkotaan dalam menunjang perkembangan kegiatan perkotaan yang cepat.

Salah satu dampak dari pemekaran kota ini adalah perubahan nilai lahan dan letak strategis suatu lahan, selanjutnya menentukan harga lahan. Harga lahan di daerah pemekaran cenderung meningkat dengan cepat sejalan dengan meningkatnya letak strategis suatu lahan karena berpindahnya fungsifungsi perkotaan di daerah ini. Hal demikian biasanya mendorong munculnya spekulasi-spekulasi tanah secara meluas.

Perubahan kategori kedua adalah perubahan yang bersifat intensif, yakni terjadinya intensifikasi pemanfaatan ruang di perkotaan. Bentuk dari intensifikasi ini adalah perubahan memadat dan perubahan vertikal. Bentu perubahan memadat di sini adalah pemanfaatan ruang/lahan yang masih kosong dan pemadatan hunian. Gejala ini bahkan dapat meluas sampai pemanfaatan lahan yang sesungguhnya tidak layak untuk permukiman tetapi terpaksa digunakan untuk tempat tinggal, seperti lahan kosong di tepi sungai dan di pinggir rel kereta api. Hal demikian apabila tidak segera diantisipasi akan menjurus pada munculnya perkam. pungan-perkampungan kumuh di kota, yang sclanjutnya akan menjadi permasalahan yang cukup rumit dalam upaya penataan ruang kota. Fenomena demikian biasanya terjadi pada para migran kelas bawah dari pedesaan yang kebanyakan bekerja pada sektor informal di 
perkotaan.

Bentuk dari perubahan vertikal adalah tumbuhnya gedung-geclung bertingkat yang menjulang. Munculnya gejala demikian berkaitan dengan terbatasnya lahan pada lokasi-lokasi yang strategis untuk kegiatan-kegiatan bisnis, perkantoran dan lainnya yang semakin meningkat. Perubahan vertikal ini biasanya diikuti dengan meningkatnya perubahan kebutuhan lahan untuk parkir kendaraan, karena pada lahan yang terbatas terdapat manusia yang banyak dan aktifitas yang tinggi.

Perkembangan vertikal di samping dapat meningkatkan efisiensi penggunaan lahan juga menimbulkan beberapa masalah lingkungan, sosial dan psikologis. Olch karena itu maka dalam upaya untuk mewujudkan lingkungan hidup kota yang nyaman, penuh variasi, mempunyai jati diri, ramah dan sehat, dampak-dampak negatif tersebut perlu diperhatikan dalam penyusunan rencana umum tataruang kota, rencana detail tata ruang kota dan rencama teknis tataruang kota.

\section{MASALAH LAHAN DI PERKOTAAN DAN ASPEK-ASPEKNYA}

Masalah lahan di perkotaan sesung. guhnya berakar pada terbatasnya persediaan lahan, sedangkan di pihak lain permintaan lahan semakin meningkat sejalan dengan meningkatnya jumlah penduduk dan aktivitas di perkotaan. Bersumber dari masalah di atas selanjutnya muncul masalah-masalah yang sesungguhnya berawal dari masalah pertama. Masalah-masalah tersebut adalah meningkatnya harga lahan secara cepat yang terkadang sulit dikendalikan, munculnya spekulasi tanah secara meluas. Munculnya masalah akibat penggusuran, munculnya masalah dalam pembebasan tanah dan masalah perbedaan kepentingan scktoral dalam penggunaan tanah.

Memang diakui, masalah mening. katnya harga tanah secara cepat dan gelombang spekulasi tanah merupakan gejala umum di kota-kota begara berkembang setelah terjadinya perkembangan ekonomi. Dalam laporan Pcrscrikatan Ekonomi Bangsa-Bangsa Tahun 1968 (dikutip dari Daldjoeni, 1987) dikemukakan;

"Spekulasi tanah di pusat-pusat perkotaan Asia telah meningkat scdemikian rupa, sehingga harga tanah di kota lebih tinggi pada negara-negara maju sekalipun".

Untuk kasus kota-kota di Indonesia Hans Dieter Evers (1982) mencmukan bahwa bentuk khas pembangunan yang terjadi di pusat- pusat kota cenderung menjurus kepada meningkatnya spekulasi tanah, dan meningkatnya pemilikan tanah secara "absentee" di kawasan pedesaan pinggiran kota. Hal demikian terjadi, seperti telah disebut di atas, karena tanah di kota akan se. makin menjadi komoditas langka, yang tcrjadi karena tidak scimbangnya antara penawaran dan permintaan. Konsekwensinya tanah di kota harganya akan meningkat dengan cepat dan sangat mudah untuk dispekulasikan. Apabila hal demikian tidak diantisipasi secara cepat dan tepat akan menjurus kepada penggunaan lahan yang tidak efisien, yang berarti pula bertentangan dengan asas pengembangan perkotaan.

Gejala lain yang berkaitan dengan masalah lahan di perkotaan adalah munculnya ketidakserasian dalam pembebasan lahan antara pihak pemilik lahan yang dibebaskan dengan pihak ca- 
lon pengguna lahan (pihak swasta dan Pemerintah), terutama dalam hal ganti rugi lahan. Kedua, dalam proses pembebasan lahan kadangkala pihak yang lahannya terkena pembebasan kurang dilibatkan secara intensif dalam proses penentuan harga ganti-rugi lahan. Ketiga, kurangnya informasi di kalangan masyarakat mengenai rencana pengem. bangan kota.

Untuk memperkecil masalah di atas, sesuai dengan UU tentang penataan ruang tahun 1992 dalam ganti rugi lahan masyarakat perlu penggantian yang layak atas kondisi yang dialaminya sebagai akibat pelaksanaan kegiatan pembangunan yang sesuai dengan rencana tataruang. Selain itu masyarakat secara langsung perlu dilibatkan dalam proses pengaturan tataruang karena pada dasarnya pembangunan adalah untuk masyarakat. Dan tidak kalah pentingnya adalah perlu semakin diintensifikasinya sosialisasi rencana tata ruang yang telah disahkan kepada masyarakat. Dalam proses penentuan ganti rugi nilai lahan nampaknya perlu ditempuh pendekatan dari bawah (botton up) yang bersifat partisipasif, berlandaskan pada asas musyawarah mufakat.

Pcrbcdaan antara instansi sektoral dalam memandang pemanfaatan lahan, kadang-kadang masih muncul. Hal demikian terjadi karena antara instansi sektoral di daerah kadangkala lebih memperhatikan arah dari departemennya daripada arahan atau rencana tataruang daerah (Budhy Tjahjadi, 1993). Oleh karena itu Bapeda yang dalam hal ini bertindak sebagai instansi koordinator dalam perencanaan dan pelaksanaan pembangunan perlu mengusahakan mekanisme koordinasi yang lebih efektif.

Masalah lain dalam kaitannya de- ngan pemanfaatan lahan perkotaan adalah benturan antara pengembangan fungsi kota scbagai pusat pelayanan dengan masalahlingkungan hidup. $\mathrm{Ada}$ kecenderungan dengan scmakin meningkatnya perkembangan kota kualitas dan daya dukung lingkungan perkotaan semakin menurun, misalnya tercermin dari semakin buruknya kondisi hidrologi, disamping indikator-indikator kualitas lingkungan yang lain.

Dengan semakin meningkatnya kepadatan bangunan dan di pihak lain luas lahan untuk peresapan air di kota semakin berkurang, maka jumlah air yang meresap dalam tanah, yang selanjutnya menjadi air tanah, semakin ber. kurang. Hal ini berarti pula aliran permukaan (run off) akan semakin besar sehingga kerentanan terhadap banjir di kota akan semakin meningkat. Namun demikian diakui memburuknya kondisi hidrologi di kota tidak semata karena faktor yang berasal dari dalam kota, tetapi juga dipengaruhi oleh perubahan kondisi daerah tangkapan. (rechange area).

Masalah persediaan air di kota akan semakin berat karena kebutuhan akan air di perkotaan, khususnya air tanah semakin meningkat sejalan dengan pertambahan penduduk kota dan mening. katnya aktivitas industri dan jasa.

Dalam kaitannya dengan masalah hidrologi di perkotaan, sebagai gambaran di Kotamadya Surakarta pada tahun 1992, kemampuan air tanah bebas untuk mengimbangi kebutuhan air penduduk sudah melampaui ambang batas. Ditemukan debit air tanah bebas besarnya $33.454,31 \mathrm{~m} 3 /$ hari, sedang. kan kebutuhan penduduk akan air saat ini setiap harinya $58.836 \mathrm{~m} 3 /$ hari. Kekurangan air disuplai dari sumber air lainnya, misalnya dari PDAM yang airnya diambil dari mata air Cokrotulung. 
Disamping itu juga ditemukan, dari data bor dalam pada tahun 1884 dan tahun 1987, muka per 20 metrik di Kotamadia Surakarta mengalami penurunan dari \pm 7,65 m menjadi $-3,40 \mathrm{~m}$ (Tim Penyusun Neraca Sumberdaya Alam Dacrah Kotamadia Dati II Surakarta, 1992).

Supaya pengembangan kota dapat optimal dan sekaligus menjaga keseimbangan dan kelestarian lingkungan kota maka diupayakan penataan penggunaan lahan dengan mempertimbangkan ekosistem kota, khususnya dampak terhadap kondisi hidrologinya.

Persoalan alih fungsi bangunan yang mempunyai nilai sejarah dan budaya untuk kegiatan bisnis atau kegiatan lain terkadang juga menimbulkan masalah yang cukup rumit untuk dipecahkan. Pengalihan fungsi bangunan demikian tidak jarang menimbulkan perbedaan pendapat yang berkepanjangan di kalangan masyarakat yang mempunyai kepentingan dan sudut pandang yang berbeda. Di satu pihak memandang bangunan yang ada tidak lagi sesuai dengan rencana tata ruang kota, tetapi di pihak lain berpendapat bangunan yang ada perlu dilestarikan sebagai monumen budaya. Beberapa kasus dapat dikemukakan di sini masalah rencana pengalihan fungsi Senisono di Yogyakarta, masalah ruislah bangunan-bangunan Mambaul Ulum dan rencana pendirian IIotel Berbintang di Surakarta.

\section{BEBERAPA PEMECAHAN}

Masalah lahan dalam kaitannya dengan pengembangan kota mempunyai aspek yang komplek dan luas. Di sam. ping persedian lahan di kota semakin terbatas, keberadaannya berkaitan de. ngan berbagai aspek seperti status pemilikan, aspek ckonomi, sosial, budaya, ckologi, estetika, bahkan aspek politik.

Oleh karenanya agar pengembangan kota dapat berjalan dengan efektif dan harmonis, maka masalah lahan perlu ditangani secara menycluruh dan terpadu dengan mengakomodasikan kepentingan masyarakat yang scluasluasnya.

Pokok-pokok pemecahan masalah penataan ruang, termasuk di dalamnya masalah pertanahan tercantum dalam UU No.24/1992 tentang Pemanfaatan Ruang.

Secara garis besar isi dari UndangUndang tersebut adalah sebagai beri. kut:

1. Penataan ruang berasaskan:

a. Pemanfaatan ruang bagi semua kepentingan secara terpadu, berdayaguna dan berhasilguna, serasi selaras, seimbang dan berkelanjutan

b. Keterbukaan, persamaan, keadilan dan perlindungan Hukum (pasal 2)

2. Penataan ruang bertujuan:

a. Terselenggaranya pemanfaatan ruang berwawasan lingkungan yang berlandaskan Wawasan Nusantara dan Ketahanan $\mathrm{Na}$ sional.

b. Terselenggaranya pengaturan pemanfaatan kawasan lindung dan kawasan budidaya.

c. Tercapainya pemanfaatan ruang yang berkualitas untuk

1. mewujudkan kehidupan bangsa yang cerdas, berbudi luhur dan sejahtera;

2. mewujudkan keterpaduan dalam penggunaan sumber- 
daya alam dan sumberdaya buatan dengan memperhatikan sumberdaya manusia;

3. Meningkatkan pemanfaatan sumberdaya alam dan sumberdaya buatan secara berdaya guna, berhasilguna, dan tcpat guna untuk meningkatkan kualitas sumber daya manusia;

4. Mewujudkan perlindungan fungsi ruang dan mencegah serta menanggulangi dampak negatif terhadap lingkungan (pasal 3);

5 Mewujudkan keseimbangan kepentingan kesejahteraan dan keamanan

3. Hak dan Kewajiban Masyarakat

a. Setiap orang herhak menikmati manfaat ruang termasuk pertambahan nilai ruang sebagai akibat penataan ruang.

b. Setiap orang berhak untuk: (pasal 4)

1. mengetahui rencana tata ruang;

2. berperan serta dalam penyusunan rencana tata ruang, pemanfaatan ruang dan pengendalian pemanfaatan ruang;

3. mempcroleh penggantian yang layak atas kondisi yang dialaminya sebagai akibat pelaksanaan kegiatan pembangunan sesuai dengan rencana tata ruang.

c. Setiap orang berkewajiban berperan serta dalam memelihara kualitas ruang

d. Setiap orang berkewajiban mentaati Rencana Tata Ruang yang tclah ditctapkan (pasal 5).

Dengan demikian masalah ruang, termasuk masalah lahan di kota dcngan berbagai aspek yang menyertainya sudah terakomodasi dalam UU penataan ruang. Tinggal sekarang scberapa jauh UU Penataan Ruang sebagai acuan dapat diimplementasikan, untuk keperluan daerah dalam bentuk Pola Dasar Pembangunan Daerah, Rencana Umum Tata Ruang Daerah, Rencana Detail Tata Ruang Daerah, maupun Rencana Teknis Tata Ruang Daerah yang tentunya disesuaikan dengan kondisi tiap-tiap daerah yang bersangkutan. *

Dalam pengendalian pemanfaatan ruang, Pemerintah Daerah perlu menyiapkan tatacara agar pemanfaatan ruang yang dilaksanakan olch masyarakat, dunia usaha maupun Pemerintah tidak menyimpang dari rencana tata ruang yang telah ditetapkan. Menurut Sugijati Tjahjati (1993); bentuk-bentuk pengendalian terhadap pemanfaatan ruang adalah antara lain:

a. Pemantauan dan evaluasi terhadap perkembangan pemanfaatan ruang;

b. Pembatalan ijin lokasi suatu kegiatan yang tidak, sesuai dengan rencana tataruang;

c. Penertiban terhadap pemanfaatan lahan yang tidak sesuai dengan rencana tata ruang;

d. Penggantian yang layak terhadap pemilik ijin yang dirugikan karena ijin lokasinya dibatalkan sedang ijin itu diperoieh dengan iktikad baik;

e. Pengenaan disinsentif untuk membatas kegiatan masyarakat di kawas. an lindung atau kawasan tertentu lainnya;

f. Pemberian insentif untuk meng. arahkan kegiatan masyarakat ke wilayah yang perlu, didorong pertum. 
buhannya.

Cara lain untuk mengatasi masalah lahan di perkotaan adalah dengan konsolidasi tanah perkotaan. De. ngan konsolidasi tanah perkotaan diharapkan kualitas lingkungan dapat meningkat dan efisiensi pemanfaatan lahan dapat dicapai melalui pemetaan dan pengaturan kembali lahan yang tersebar dan tidak teratur. Setelah itu lahan dibagikan kembali kepada para pemiliknya dalam bentuk yang sudah teratur dan dilengkapi prasarana. Dengan demikian maka, menurut Jayadinata (1992), tujuan konsolidasi tanah terkontrol dan meningkatkan cara pengembangan kota dengan lebih adil dan bernilai sosial.

Konsolidasi tanah perkotaan meliputi aturan-aturan berikut:

1. Pemetaan kembali secra wajib (compulsory reparcelation) atau disebut dengan penyesuaian kembali, yaitu pengaturan bentuk dan luas (petak) yang disesuaikan dengan lokasi dan rencana lokal.

2. Penjualan tanah bertahap (interim) secara wajib. Pemerintah membcli tanah dari pemilik, dan setelah diadakan pengaturan petak, tanah tersebut dijual kembali kepada orang/Badan yang membutuhkan.

3. Konsolidasi tanah pertanian dan kehutanan bagi pengembangan kota, Tanah pertanian atau tanah, kchutanan, dengan persetujuan pemiliknya dijual dan digunakan untuk fungsi perkotaan.

Dengan mengingat ternyata permasalahan pertanahan wilayah perkotaan di Indonesia adalah bagaimana menda. yagunakan dan menghasilgunakan tata guna tanah yang terbatas luasnya, maka konsolidasi tanah dapat merupakan salah sath model dalam pengembangan pertanahan di kota-kota di Indonesia. Menurut Jayadinata (1992), konsolidasi tanah dalam kota, dilihat dari scgi sosial sangat berguna dalam menanggulangi kcbutuhan akan pcrumahan dan dalam memberikan prasarana sosial kepada penduduk kota secara lebih mereta. Beberapa keuntungan sosial dari konsolidasi tanah di perkotaan dapat dikemukakan di sini, seperti:

1. Pemilik tanah akan memperoleh kembali tanah bcrupa petak tanah yang bentuknya tcratur dan dekat dengan prasarana lingkungan;

2. Taraf kehidupan penduduk dapat ditingkaskan dengan mengatur permukiman sehingga menjadi sehat dan tertib;

3. Konflik dalam penggunaan tanah dapat dihindari dengan tertibnya kualitas lingkungan;

4. Beban pusat kota yang berlebihan dapat dikurangi karena tersedianya prasarana sosial ekonomi yang memadai di sektor permukiman;

5. Pengendalian pengembangan tanah (land development control) lcbih mudah dilakukan;

6. Perkembangan permukiman liar dapat dicegah.

Sedangkan dilihat dari segi ekonomi, konsolidasi tanah perkotaan mem. punyai keuntungan-keuntungan sebagai berikut:

1. Meringankan pembiayaan Pemerintah dalam pengembangan kota;

2. Bagi pemilik tanah tidak perlu mengeluarkan biaya khusus dalam me. matangkan tanah;

3. Memberikan kcmungkinan kepada penduduk kota dari berbagai lapisan, untuk dapat membangun sesuai kemampuan masing-masing;

4. Memudahkan Pemerintah melaku. 
kan investasi maupun menghadapi investor swasta atau investor asing dalam penyediaan lokasi industri;

5. Menghambat terjadinya spekulasi tanah di wilayah yang akan dikem. bangkan olch golongan ckonomi kuat, melalui pengendalian penyediaan tanah menurut luas, lokasi, kualitas, harga serta waktu yang scsuai dengan pentahapan perencanaan kota.

Dalam penerapannya, untuk Pemerintah setempat yang belum berpengalaman dalam konsolidasi tanah, se. baiknya dimulai dengañ menerepkan di daerah pinggiran kota, karena permasalahan di bagian tengah kota, lebih-lcbih di pusat kota sangat rumit. Di samping itu supaya model konsolidasi tanah dapat diterapkan, maka periu disesuaikan dengan kondisi setempat.

\section{PENUTUP}

Masalah pengelolaan lahan di perkotaan terkait dengan berbagai aspek, dan tidak jarang para pengelola kota di hadapan pilihan-pilihan yang dilematis. Inensifikasi pemanfaatan lahan dan perluasan kota menjalin tuntutan yang semakin mendesak sebagai akibat logis dari perkembangan kota (Urban Development).

Di pihak lain intensifikasi pemanfaatan lahan kota tidak jarang mendorong menurunnya kualitas dan daya dukung lingkungan perkotaan; meluasnya spekulasi harga lahan yang selanjutnya mendorong inefisiensi penggunaan lahan perkotaan dan sering memicu konflik sosial dalam kaitannya dengan alih fungsi lahan. Pemekaran kota (urban sprawl) khususnya pada kotakota di Jawa semakin mengurangi lahan pertanian yang subur. Ini berarti target kebijakan mengenai pangan (baca swa-sembada beras) akan sedikit banyak terganggu.

Didasarkan pada kompleksnya persoalan lahan di perkotaan seperti disinggung di atas maka diperlukan suatu strategi terpadu dan menyeluruh yang dapat mengakomodasikan semua kepentingan dan aspek yang tekait.

\section{DAFTAR RUJUKAN}

Evers, Hans Dieter, 1982. Sosiologi Perkotaan: Urbanisasi dan Sengketa Tanah di Indonesia dan Malaysia. Jakarta LP3ES.

Daldjoeni, Nathael, 1987. Geografi Desa-Kota, Bandung, Alumni.

Dilahur, 1990. Kuburan di Perkotaan Dalam Perubahan Keruangan; Forum Geografi No.7 (IV), Fakultas Gcografi UMS.

Jayadinata, J.T., 1992. Tata Guna Tanah Dalam Pcrencanaan Pedesaan, Perkotaan dan Wilayah, Bandung, ITB.

Soemadhijo, Rachmadi, B., 1993. Kajian Terhadap Perbandingan Kota dan Wilayah Dalam Dua Dasawarsa Terakhir, Makalah Seminar Nasional Pengembangan Profesi Perencanaan, 25-26 Mci 1993 di Jakarta.

Sugandhy, Aca, 1992. Penerapan Undang-Undang Tentang Penataan Ruang Untuk Penataan Lokasi, Kawasan di Daerah, Makalah Seminar Bahasan Implementasi Undang-Undang Tentang Penataan Ruang, Tinjauan Dari Sudut Pandang Lingkungan Hidup, 12 Desember 1992 di UGM Yogyakarta.

Tjahjati, Budhi, 1993. Usaha-Usaha Dacrah Dalam Penataan Ruang Kota dan Daerah, Makalah Seminar Nasional Pengembangan Profesi Perencanaan, 22-26 Mei 1992 di Jakarta. 